\title{
Ammonia Oxidation and Nitrite Reduction in the Verrucomicrobial Methanotroph Methylacidiphilum fumariolicum SolV
}

OPEN ACCESS

Edited by:

Martin Koenneke,

MARUM - Center for Marine Environmental Sciences, University of Bremen, Germany

Reviewed by:

Lisa Y. Stein,

University of Alberta, Canada Ronald Oremland, United States Geological Survey,

United States

*Correspondence:

Huub J. M. Op den Camp

h.opdencamp@science.ru.nl

Specialty section:

This article was submitted to Microbial Physiology and Metabolism,

a section of the journal

Frontiers in Microbiology

Received: 02 August 2017 Accepted: 15 September 2017

Published: 27 September 2017

Citation:

Mohammadi SS, Pol A, van Alen T, Jetten MSM and Op den Camp HJM (2017) Ammonia Oxidation and Nitrite

Reduction in the Verrucomicrobial Methanotroph Methylacidiphilum fumariolicum Solv

Front. Microbiol. 8:1901. doi: 10.3389/fmicb.2017.01901

\section{Sepehr S. Mohammadi, Arjan Pol, Theo van Alen, Mike S. M. Jetten and Huub J. M. Op den Camp*}

Department of Microbiology, Faculty of Science, Institute for Water and Wetland Research, Radboud University, Nijmegen, Netherlands

The Solfatara volcano near Naples (Italy), the origin of the recently discovered verrucomicrobial methanotroph Methylacidiphilum fumariolicum SolV was shown to contain ammonium $\left(\mathrm{NH}_{4}^{+}\right)$at concentrations ranging from 1 to $28 \mathrm{mM}$. Ammonia $\left(\mathrm{NH}_{3}\right)$ can be converted to toxic hydroxylamine $\left(\mathrm{NH}_{2} \mathrm{OH}\right)$ by the particulate methane monooxygenase (pMMO), the first enzyme of the methane $\left(\mathrm{CH}_{4}\right)$ oxidation pathway. Methanotrophs rapidly detoxify the intermediate $\mathrm{NH}_{2} \mathrm{OH}$. Here, we show that strain SolV performs ammonium oxidation to nitrite at a rate of $48.2 \mathrm{nmol} \mathrm{NO}-\mathrm{n}^{-1} \cdot \mathrm{mg} \mathrm{DW}^{-1}$ under $\mathrm{O}_{2}$ limitation in a continuous culture grown on hydrogen $\left(\mathrm{H}_{2}\right)$ as an electron donor. In addition, strain SolV carries out nitrite reduction at a rate of $74.4 \mathrm{nmol} \mathrm{NO}-\mathrm{n}^{-1} \cdot \mathrm{mg} \mathrm{DW}^{-1}$ under anoxic condition at $\mathrm{pH} 5-6$. This range of $\mathrm{pH}$ was selected to minimize the chemical conversion of nitrite $\left(\mathrm{NO}_{2}^{-}\right)$potentially occurring at more acidic $\mathrm{pH}$ values. Furthermore, at $\mathrm{pH} 6$, we showed that the affinity constants $\left(\mathrm{K}_{s}\right)$ of the cells for $\mathrm{NH}_{3}$ vary from 5 to $270 \mu \mathrm{M}$ in the batch incubations with $0.5-8 \%(\mathrm{v} / \mathrm{v}) \mathrm{CH}_{4}$, respectively. Detailed kinetic analysis showed competitive substrate inhibition between $\mathrm{CH}_{4}$ and $\mathrm{NH}_{3}$. Using transcriptome analysis, we showed up-regulation of the gene encoding hydroxylamine dehydrogenase (haoA) cells grown on $\mathrm{H}_{2} / \mathrm{NH}_{4}^{+}$compared to the cells grown on $\mathrm{CH}_{4} / \mathrm{NO}_{3}^{-}$which do not have to cope with reactive $\mathrm{N}$-compounds. The denitrifying genes nirk and nor $\mathrm{C}$ showed high expression in $\mathrm{H}_{2} / \mathrm{NH}_{4}^{+}$and $\mathrm{CH}_{4} / \mathrm{NO}_{3}^{-}$grown cells compared to cells growing at $\mu_{\max }$ (with no limitation) while the norB gene showed downregulation in $\mathrm{CH}_{4} / \mathrm{NO}_{3}^{-}$grown cells. These cells showed a strong upregulation of the genes in nitrate/nitrite assimilation. Our results demonstrate that strain SolV can perform ammonium oxidation producing nitrite. At high concentrations of ammonium this may results in toxic effects. However, at low oxygen concentrations strain SolV is able to reduce nitrite to $\mathrm{N}_{2} \mathrm{O}$ to cope with this toxicity.

Keywords: Methylacidiphilum, methanotroph, ammonia, methane, nitrite, reactive $\mathbf{N}$ compounds

\section{INTRODUCTION}

Methane $\left(\mathrm{CH}_{4}\right)$ is a powerful greenhouse gas, which is released in to the atmosphere both from natural and anthropogenic sources (Conrad, 2009). Understanding sources and sinks of $\mathrm{CH}_{4}$ is important for future models of climate change on our planet. Methane oxidizing microorganisms are one of the most important biological sinks of $\mathrm{CH}_{4}$ (Murrell and Jetten, 2009). 
Aerobic methanotrophic bacteria belong to a physiological group of bacteria recognized as methylotrophs. The proteobacterial methanotrophs are distinctive in their ability to exploit $\mathrm{CH}_{4}$ as the only carbon and energy source (Hanson and Hanson, 1996). Recently, three independent research groups discovered extreme acidophilic methanotrophic Verrucomicrobia in geothermal regions (Dunfield et al., 2007; Pol et al., 2007; Islam et al., 2008). Prior to this finding, obligate aerobic methanotrophs were speculated to be exclusively represented in the Alpha and Gamma subclasses of the Proteobacteria. Analysis of the $16 \mathrm{~S}$ ribosomal RNA and $p m o A$ genes demonstrated that the new Verrucomicrobia species do not form a monophyletic group with this subclasses (Heyer et al., 2005), and the new genus name Methylacidiphilum was suggested (Op den Camp et al., 2009). Furthermore, it has been shown that growth of the new acidophilic methanotrophic bacterium Methylacidiphilum fumariolicum SolV is strictly dependent on the presence of lanthanides acting as a cofactor of the methanol dehydrogenase (Keltjens et al., 2014; Pol et al., 2014). Recently, new species of mesophilic acidophilic verrucomicrobial methanotrophs were isolated and characterized from a volcanic region in Italy and the new genus Methylacidimicrobium was proposed (Sharp et al., 2014; van Teeseling et al., 2014). This finding expands the diversity of verrucomicrobial methanotrophs and demonstrates that they could be present in more ecosystems than formerly supposed (Chistoserdova et al., 2009). The new verrucomicrobial strains from both genera were shown to be autotrophs that use $\mathrm{CH}_{4}$ as the sole energy source and fix $\mathrm{CO}_{2}$ using the CalvinBenson-Bassham Cycle (Khadem et al., 2011; Sharp et al., 2012, 2013, 2014; van Teeseling et al., 2014), and strain SolV was shown to be able to fix $\mathrm{N}_{2}$ (Khadem et al., 2010).

Methanotrophic and nitrifying microorganisms share many similarities. They grow obligately on the specific substrates, $\mathrm{CH}_{4}$ for methanotrophs and $\mathrm{NH}_{3}$ for nitrifiers. These molecules are structurally comparable and both are highly reduced. Many of these types of microorganisms have intracellular membrane structures where the membrane bound ammonia monooxygenase (AMO) or $\mathrm{CH}_{4}$ monooxygenase (pMMO) are localized. In the first step of aerobic $\mathrm{CH}_{4}$ or $\mathrm{NH}_{3}$ oxidation, the monooxygenase enzymes introduce a single oxygen atom from $\mathrm{O}_{2}$ into $\mathrm{CH}_{4}$ or $\mathrm{NH}_{3}$, producing methanol from $\mathrm{CH}_{4}$ and hydroxylamine from $\mathrm{NH}_{3}$ (Stein et al., 2012). Both microorganisms are able to co-oxidize a range of other substrates and are inhibited by similar compounds (Bédard and Knowles, 1989; Stein et al., 2012). Nitrifiers are able to oxidize $\mathrm{CH}_{4}$, and methanotrophs are capable of nitrification. It has been shown that in nutrient limited situations, methanotrophs do participate in soil nitrification, mainly in the production of $\mathrm{N}_{2} \mathrm{O}$. Nitrification by aerobic methanotrophs relies on $\mathrm{CH}_{4}$, because they cannot grow on $\mathrm{NH}_{3}$ (Stein et al., 2012). Recent studies of $\mathrm{CH}_{4}$ oxidation and $\mathrm{N}_{2} \mathrm{O}$ production in soils using stable isotopes and particular inhibitors offered more evidence for a role of methanotrophic bacteria in nitrification (Mandernack et al., 2000; Lee et al., 2009; Acton and Baggs, 2011; Im et al., 2011).

$\mathrm{NH}_{4}^{+}$is a nitrogen source for methanotrophic bacteria but was also shown to inhibit $\mathrm{CH}_{4}$ oxidation in the model organism Methylosinus sporium, especially due to accumulation of $\mathrm{NO}_{2}^{-}$(He et al., 2017). The pMMO enzyme catalyzing the first step of $\mathrm{CH}_{4}$ oxidation in methanotrophs, also oxidizes $\mathrm{NH}_{3}\left(\mathrm{NH}_{4}^{+}\right)$to hydroxylamine $\left(\mathrm{NH}_{2} \mathrm{OH}\right.$; Hanson and Hanson, 1996; Nyerges and Stein, 2009; Stein and Klotz, 2011; Stein et al., 2012). Ammonia-oxidizers can convey electrons from hydroxylamine oxidation to the quinone pool to conserve energy and support cellular growth (Klotz and Stein, 2008), but methanotrophs lack this system and cannot conserve energy from this oxidation. Since the intermediate $\mathrm{NH}_{2} \mathrm{OH}$ is highly toxic, methanotrophs use mechanisms to quickly detoxify it. In the natural environment strain SolV cells are faced with 1-28 $\mathrm{mM} \mathrm{NH}_{4}^{+}$concentrations (Khadem et al., 2010) meaning that the cells have to balance assimilation and tolerance in response to reactive- $\mathrm{N}$ molecules. Detoxification can be achieved by conversion of $\mathrm{NH}_{2} \mathrm{OH}$ back to $\mathrm{NH}_{4}^{+}$ or to $\mathrm{NO}_{2}^{-}$using a hydroxylamine dehydrogenase enzyme. Nitrite, which is also toxic, can be further converted to nitrous oxide $\left(\mathrm{N}_{2} \mathrm{O}\right)$ via toxic nitric oxide $(\mathrm{NO})$ by denitrification enzymes under anoxic conditions (Campbell et al., 2011). Recently, Kits et al. (2015) reported the reduction of nitrate coupled with aerobic methane oxidation under extreme oxygen limited conditions in which $\mathrm{N}_{2} \mathrm{O}$ production was directly supported by $\mathrm{CH}_{4}$ oxidation in Methylomonas denitrificans strain FJG1 ${ }^{\mathrm{T}}$.

In the genome of strain SolV, genes encoding enzymes responsible for $\mathrm{NO}_{2}^{-}$reduction (nirK) and $\mathrm{NO}$ reduction (norB encoding the catalytic subunit, norC encoding the electronaccepting subunit), were identified but the gene encoding $\mathrm{N}_{2} \mathrm{O}$ reductase was absent. A hao $A B$ gene cluster encoding hydroxylamine dehydrogenase was also identified, suggesting the ability of nitrification and handling of reactive N-compounds (Khadem et al., 2012c; Anvar et al., 2014). Previously a $\mathrm{pH}$ of 2-3 has been used for physiological studies of strain SolV (Khadem et al., 2010, 2011, 2012a,b,c). However, since strain SolV has a rather broad $\mathrm{pH}$ range for growth (Pol et al., 2007) and can be easily adapted to grow at higher $\mathrm{pH}$ values, we used the $\mathrm{pH}$ range of 5-6 in the present study. This minimized the chemical conversion of $\mathrm{NO}_{2}^{-}$ occurring at acidic pH (Matthew et al., 2005; Ryabenko et al., 2009).

Recently, using growth experiments (batch and continuous cultures) together with transcriptome and kinetics analyses, M. fumariolicum SolV was shown to be able to grow as a real "Knallgas" bacterium on hydrogen/carbon dioxide, without addition of $\mathrm{CH}_{4}$ (Mohammadi et al., 2017). Cells grown on $\mathrm{H}_{2}$ still express active pMMO similar to the $\mathrm{CH}_{4}$ culture (Mohammadi et al., 2017). Since we hypothesized that the $\mathrm{NH}_{4}^{+}$ oxidation is limited by the presence of $\mathrm{CH}_{4}$, we tested $\mathrm{NH}_{4}^{+}$ oxidation to $\mathrm{NO}_{2}^{-}$using a continuous culture grown on hydrogen in the absence of $\mathrm{CH}_{4}$ (Mohammadi et al., 2017). Furthermore, we examined the affinity of cells for $\mathrm{NH}_{4}^{+}$using batch cultures with different concentrations of $\mathrm{CH}_{4}$ in a range of $0.5-8 \%$ $(\mathrm{v} / \mathrm{v})$. The aim of this study was first to investigate whether strain SolV can perform $\mathrm{NH}_{4}^{+}$oxidation, and secondly, how it could detoxify the reactive $\mathrm{N}$-compounds resulting from this oxidation using physiological experiments and transcriptome analysis. 


\section{MATERIALS AND METHODS}

\section{Microorganism and Medium Composition}

M. fumariolicum strain SolV used in this study was initially isolated from the volcanic region Campi Flegrei, near Naples, Italy (Pol et al., 2007). In this study the medium to obtain an $\mathrm{OD}_{600}$ of 1.0 was composed of $0.2 \mathrm{mM} \mathrm{MgCl} 2.6 \mathrm{H}_{2} \mathrm{O} ; 0.2 \mathrm{mM}$ $\mathrm{CaCl}_{2} .2 \mathrm{H}_{2} \mathrm{O} ; 1 \mathrm{mM} \mathrm{Na} 2 \mathrm{SO}_{4} ; 2 \mathrm{mM} \mathrm{K}_{2} \mathrm{SO}_{4} ; 2 \mathrm{mM}\left(\mathrm{NH}_{4}\right)_{2} \mathrm{SO}_{4}$ (or $5 \mathrm{mM} \mathrm{KNO}$ ) and $1 \mathrm{mM} \mathrm{NaH} \mathrm{PO}_{4} \cdot \mathrm{H}_{2} \mathrm{O}$. A trace element solution containing $1 \mu \mathrm{M} \mathrm{NiCl}_{2}, \mathrm{CoCl}_{2}, \mathrm{MoO}_{4} \mathrm{Na}_{2}, \mathrm{ZnSO}_{4}$ and $\mathrm{CeCl}_{3} ; 5 \mu \mathrm{M} \mathrm{MnCl}_{2}$ and $\mathrm{FeSO}_{4} ; 10 \mu \mathrm{M} \mathrm{CuSO}_{4}$ and $40-50 \mu \mathrm{M}$ nitrilotriacetic acid (NTA). The $\mathrm{pH}$ of medium was adjusted to 2.7 using $1 \mathrm{M} \mathrm{H}_{2} \mathrm{SO}_{4}\left(1 \mathrm{ml} \mathrm{H}_{2} \mathrm{SO}_{4}\right.$ per $1 \mathrm{~L}$ medium). To avoid precipitation, $\mathrm{CaCl}_{2} \cdot 2 \mathrm{H}_{2} \mathrm{O}$ and the rest of medium were autoclaved separately and mixed after cooling. This medium composition was used in batch and continuous cultures, unless otherwise stated.

\section{Chemostat Cultivation}

The continuous culture with $\mathrm{CH}_{4}$ as an electron donor and nitrate $\left(\mathrm{NO}_{3}^{-}\right)$as $\mathrm{N}$-source $\left(\mathrm{CH}_{4} / \mathrm{NO}_{3}^{-}\right)$, liquid volume $500 \mathrm{ml}$, was operated at $55^{\circ} \mathrm{C}$ with stirring at $900 \mathrm{rpm}$ with a stirrer bar. The chemostat was supplied with medium at a flow rate of $14.5 \mathrm{ml} . \mathrm{h}^{-1}\left(D=0.026 \mathrm{~h}^{-1}\right)$, using a peristaltic pump. The cell-containing medium was removed automatically from the chemostat by a peristaltic pump when the liquid level reached the $500 \mathrm{ml}$ level sensor in the reactor. A supply of $10 \% \mathrm{CH}_{4}$ $(\mathrm{v} / \mathrm{v}), 8 \% \mathrm{O}_{2}(\mathrm{v} / \mathrm{v})$, and $68 \% \mathrm{CO}_{2}(\mathrm{v} / \mathrm{v})$ took place by mass flow controllers through a sterile filter and was sparged into the medium just above the stirrer bar (total gas flow rate $\approx 20 \mathrm{ml} \cdot \mathrm{min}^{-1}$ ). The initial $\mathrm{pH}$ was 3.4 and was regulated with $1 \mathrm{M}$ carbonate connected to the vessel by a peristaltic pump. The pH was gradually increased to 6 and after obtaining a steady state, all experiments were performed at this $\mathrm{pH}$. In the continuous culture with $\mathrm{H}_{2}$ as an electron donor and $\mathrm{NH}_{4}^{+}$as $\mathrm{N}$-source $\left(\mathrm{H}_{2} / \mathrm{NH}_{4}^{+}\right)$, liquid volume was $1.2 \mathrm{~L}$ and this culture was operated at $55^{\circ} \mathrm{C}$ with stirring at $1,000 \mathrm{rpm}$. The chemostat was supplied with medium at a flow rate of $29.9 \mathrm{ml}^{-1}\left(D=0.023 \mathrm{~h}^{-1}\right)$. A gas supply of $12 \% \mathrm{H}_{2}(\mathrm{v} / \mathrm{v}), 10 \%$ air $(\mathrm{v} / \mathrm{v})$, and $5 \% \mathrm{CO}_{2}(\mathrm{v} / \mathrm{v})$ was provided by mass flow controllers through a sterile filter and sparged into the medium (total gas flow rate $\approx 16.5 \mathrm{ml} . \mathrm{min}^{-1}$ ). The initial $\mathrm{pH}$ was 2.9 and the $\mathrm{pH}$ was regulated by $1 \mathrm{M} \mathrm{NaOH}$. A pH range from 3 to 5.5 was investigated in the steady state. In the continuous culture with $\mathrm{CH}_{4}$ as an electron donor and $\mathrm{NH}_{4}^{+}$ as $\mathrm{N}$-source $\left(\mathrm{CH}_{4} / \mathrm{NH}_{4}^{+}\right)$, the liquid volume was $0.3 \mathrm{~L}$ and the culture was operated at $55^{\circ} \mathrm{C}$ with stirring at $700 \mathrm{rpm}$ at $\mathrm{pH}$ 2.7. The chemostat was supplied with medium at a flow rate of 0.35 $\mathrm{ml} . \mathrm{h}^{-1}\left(D=0.0012 \mathrm{~h}^{-1}\right)$. A gas supply of $0.16 \% \mathrm{CH}_{4}(\mathrm{v} / \mathrm{v}), 0.6 \%$ $\mathrm{O}_{2}(\mathrm{v} / \mathrm{v})$, and $5 \% \mathrm{CO}_{2}(\mathrm{v} / \mathrm{v})$ was directed by mass flow controllers through a sterile filter and sparged into the medium (total gas flow rate $\approx 10 \mathrm{ml} \cdot \mathrm{min}^{-1}$ ). An $\mathrm{O}_{2}$ sensor in the liquid was coupled to a Biocontroller (Applikon) regulating the $\mathrm{O}_{2}$ mass controller in each reactor.

\section{Batch Cultivation}

In order to obtain cells growing at maximum growth rate $\left(\mu_{\max }\right)$, cells were grown without any limitation in 250-ml serum bottles containing $40 \mathrm{ml}$ medium ( $4 \mathrm{mM} \mathrm{NH}_{4}^{+}$; $\mathrm{pH} 2.7$ ), and sealed with red butyl rubber stoppers. The headspace contained air with $(\mathrm{v} / \mathrm{v})$ $10 \% \mathrm{CH}_{4}, 5 \% \mathrm{CO}_{2}$ at $55^{\circ} \mathrm{C}$ with shaking at $250 \mathrm{rpm}$. Incubations were performed in duplicate.

\section{Gas Analysis}

Nitric oxide and nitrous oxide ( $\mathrm{NO}$ and $\mathrm{N}_{2} \mathrm{O}$ ) were analyzed on an Agilent series 6890 gas chromatograph (Agilent, USA) equipped with a Porapak Q and a Molecular sieve column, coupled to a thermal conductivity detector and a mass spectrometer (MS; Agilent 5975 Cinert MSD; Agilent, USA) as described before (Ettwig et al., 2008). For all gas analyses, $100 \mu \mathrm{l}$ gas samples were injected into the gas chromatograph. Furthermore, nitric oxide production was monitored directly from the gas outlet of the reactors using a nitric oxide analyzer (NOA 280i, GE) with a suction rate of $11.6 \mathrm{ml} . \mathrm{min}^{-1}$.

\section{Dry-Weight Determination and Elemental Analysis}

To determine the dry weight, samples of $8-10 \mathrm{ml}$ from the culture suspension were filtered through pre-weighed $0.45 \mu \mathrm{m}$ filters and dried to constant weight in a vacuum oven at $70^{\circ} \mathrm{C}$ $(n=3)$. In order to determine the total content of carbon and nitrogen, $10 \mathrm{ml}$ of the culture suspension (duplicate) was centrifuged at 4,500 $\mathrm{g}$ for $30 \mathrm{~min}$ and the clear supernatant was used for the analysis. The nitrogen and carbon content in the supernatant was compared with the corresponding values in the whole cell suspension. The total carbon and nitrogen contents were measured using TOC-L and TNM-1 analyzers (Shimadzu).

\section{Nitrite, Ammonium, and Hydroxylamine Analysis}

To determine nitrite $\left(\mathrm{NO}_{2}^{-}\right)$concentrations, $50 \mu \mathrm{l}$ of sample, and $450 \mu \mathrm{l}$ of MilliQ water were added to a cuvette. Then, 500 $\mu l$ of reagent $A[1 \%(\mathrm{w} / \mathrm{v})$ sulfanilic acid in $1 \mathrm{M} \mathrm{HCl}$; kept in the dark] and $500 \mu \mathrm{l}$ of reagent B [0.1\% (w/v) naphtylethylene diaminedihydrochloride (NED) in water; kept at $4^{\circ} \mathrm{C}$ in the dark] were added to the same cuvette and mixed well. After incubation for $10 \mathrm{~min}$ at room temperature, the absorbance at $540 \mathrm{~nm}$ was measured and the values were compared with a calibration curve using known concentrations of nitrite in a range of $0-0.5 \mathrm{mM}$. If necessary, the sensitivity of this assay could be increased 10 -fold using $500 \mu \mathrm{l}$ samples without addition of water. $\mathrm{NH}_{4}^{+}$concentrations were measured using the ortho phthaldialdehyde (OPA) method (Taylor et al., 1974). In order to determine hydroxylamine concentrations, $200 \mu$ l reagent A ( $50 \mathrm{mM}$ potassium phosphate buffer $\mathrm{pH} 7$ ), $160 \mu$ l demineralized water, $200 \mu \mathrm{l}$ sample, $40 \mu \mathrm{l}$ reagent B [12\% (w/v) trichloroacetic acid in water, kept in the dark], $200 \mu \mathrm{l}$ reagent $\mathrm{C}(1 \% \mathrm{w} / \mathrm{v} 8$ hydroxyquinoline (quinolinol) in 100\% ethanol, kept in the dark) and $200 \mu \mathrm{l}$ reagent $\mathrm{D}\left(1 \mathrm{M} \mathrm{Na}_{2} \mathrm{CO}_{3}\right)$ were mixed and incubated at $100^{\circ} \mathrm{C}$ for $1 \mathrm{~min}$. The absorption was measured at $705 \mathrm{~nm}$ and the values were compared to a calibration curve using hydroxylamine concentrations $0.02-0.1 \mathrm{mM}$. 


\section{Activity Assays}

To determine the affinity constant of pMMO for $\mathrm{NH}_{3}$ of each sample, a volume of $5 \mathrm{ml}$ of cells from the $\mathrm{CH}_{4} / \mathrm{NO}_{3}^{-}$continuous culture were washed and resuspended in the same medium at $\mathrm{pH} 6$ (The $\mathrm{pH}$ of the medium was adjusted to 6 using MES buffer at a final concentration of $25 \mathrm{mM}$ ), transferred to a 60 $\mathrm{ml}$ serum bottle and capped. After a pre-incubation for $30 \mathrm{~min}$, $\mathrm{CH}_{4}$ was added to each bottle at final concentrations of 0.5 , $1,2,3,4$, and $8 \%(\mathrm{v} / \mathrm{v})$. To each incubation, with a certain concentration of $\mathrm{CH}_{4}, \mathrm{NH}_{4}^{+}$was added in a range of $0.5-16 \mathrm{mM}$. The initial production of $\mathrm{NO}_{2}^{-}$was measured, and the values were normalized to the total protein content of the cells. Incubations were performed at $55^{\circ} \mathrm{C}$ and shaking at $380 \mathrm{rpm}$. Each condition was performed in duplicate and values did not deviate more than $5 \%$.

\section{RNA Isolation and Transcriptome Analysis}

The complete genome sequence of strain SolV (Anvar et al., 2014), which is also available at the MicroScope annotation platform (https://www.genoscope.cns.fr/agc/microscope/ home/), was used as the template for the transcriptome analysis (RNA-seq). A 4 -ml volume of cells $\left(\mathrm{OD}_{600}=1\right)$ was sampled from the continuous cultures $\left(\mathrm{H}_{2}\right.$ and $\mathrm{CH}_{4}$ grown cells under $\mathrm{O}_{2}$ limitation) and from a batch culture (cells at $\mu_{\max }$ grown on $\mathrm{CH}_{4}$ without limitation) and harvested by centrifugation. The pellet was further used for mRNA isolation using the RiboPure $^{\mathrm{TM}}$-Bacteria Kit according to the manufacturer's protocol (ThermoFisher, Waltham, USA). Briefly, cells were disrupted by cold Zirconia beads and after centrifugation, 0.2 volumes of chloroform was added to the supernatant for initial RNA purification. Next, 0.5 volumes of $100 \%$ ethanol was added to the aqueous phase obtained after chloroform addition and the whole sample was transferred to a filter cartridge. After washing, the RNA was eluted from the filter cartridge. Afterwards, using MICROBexpress ${ }^{\mathrm{TM}}$ kit (ThermoFisher, Waltham, USA) the ribosomal RNAs were removed from the total RNA. The rRNA removal efficiency was checked using the Agilent 2100 Bioanalyzer (Agilent, Santa Clara, USA). Next, Ion Total RNASeq Kit v2 (ThermoFisher, Waltham, USA) was used to construct the cDNA libraries from rRNA-depleted total RNA. Briefly, the rRNA-depleted total RNA was fragmented using RNase III and then, reverse transcription was performed on the fragmented RNAs. The obtained cDNAs were amplified and further purified to prepare barcoded libraries. To prepare the template for the Ion Personal Genome Machine ${ }^{\circledR}\left(\mathrm{PGM}^{\mathrm{TM}}\right)$ System, a volume of $15 \mu \mathrm{l}$ from two sample libraries with a concentration of $14 \mathrm{pM}$ were mixed. This mixture of two libraries was used to prepare the template-positive Ion Sphere ${ }^{\mathrm{TM}}$ particles (ISPs) using the Ion OneTouch $^{\mathrm{TM}} 2$ instrument. Afterwards, the template-positive ISPs were enriched using the Ion OneTouch ${ }^{\mathrm{TM}}$ ES instrument. Both template preparation and enrichment were performed using the Ion PGM ${ }^{\mathrm{TM}}$ Template OT2 200 Kit (Ion Torrent, Life technologies). Enriched templates were sequenced on an Ion $318^{\mathrm{TM}}$ Chip v2 using the Ion $\mathrm{PGM}^{\mathrm{TM}}$ sequencing $200 \mathrm{Kit}$ v2. Expression analysis was performed with the RNA-seq Analysis tool from the CLC Genomic Work bench software (version 7.0.4, CLC-Bio, Aarhus, Denmark). The sequencing reads were first mapped to the ribosomal RNA operon and all tRNA and ncRNA genes, and mapped reads were discarded. The remaining reads were mapped to the CDS sequences extracted from the genome sequence of strain SolV (Anvar et al., 2014). Expression values are given as RPKM (Reads per Kilo base of exon model per Million mapped reads; Mortazavi et al., 2008). The total number of reads obtained and mapped on the coding sequences of the genome for each sample together with the calculated expression levels (RPKM) is provided in the Supplementary Material (Table S1).

\section{RESULTS}

\section{Physiological Tests Regarding Ammonium Oxidation to Nitrite and Nitrite Reduction to $\mathrm{N}_{\mathbf{2}} \mathrm{O}$}

To study the effect and conversion of nitrogenous compounds, three different continuous cultures were used which are referred to as $\mathrm{CH}_{4} / \mathrm{NH}_{4}^{+}, \mathrm{H}_{2} / \mathrm{NH}_{4}^{+}$, and $\mathrm{CH}_{4} / \mathrm{NO}_{3}^{-}$. In the second and third cultures, oxygen was limiting. Using a $\mathrm{NOx}$ analyzer and GC-MS, we demonstrated that in the $\mathrm{CH}_{4} / \mathrm{NH}_{4}^{+}$culture with low actual $\mathrm{CH}_{4}$ concentrations in the liquid $(0.3 \mu \mathrm{M})$ and with $\mathrm{NH}_{4}^{+}(4 \mathrm{mM}), \mathrm{NO}_{2}^{-}$was not detected, and $\mathrm{N}_{2} \mathrm{O}$ production rate was only $0.015 \mathrm{nmol} \mathrm{N}_{2} \mathrm{O} . \mathrm{h}^{-1}$. $\mathrm{mg} \mathrm{DW}^{-1}$ (Table 1) which was 12,000 -fold less than the $\mathrm{CH}_{4}$ conversion rate $\left(180 \mathrm{nmol}^{-1} \mathrm{~h}^{-1} \cdot \mathrm{mg}\right.$ $\mathrm{DW}^{-1}$ ). To increase $\mathrm{NO}_{2}^{-}$concentrations and study potential toxic effects of this compound, we used the $\mathrm{H}_{2} / \mathrm{NH}_{4}^{+}$continuous culture applying different conditions. Initially, the production of $\mathrm{NO}_{2}^{-}, \mathrm{NO}$, and $\mathrm{N}_{2} \mathrm{O}$ were measured under steady state conditions at a $\mathrm{pH}$ range of 3-5.5 under $\mathrm{O}_{2}$ limitation (Figure 1). We showed that the $\mathrm{NO}_{2}^{-}$, $\mathrm{NO}$ and $\mathrm{N}_{2} \mathrm{O}$ concentrations were elevated by increasing the $\mathrm{pH}$ from 3 to 5.5 in the presence of $4 \mathrm{mM} \mathrm{NH}_{4}^{+}$. Changing $\mathrm{pH}$ from 3 to 5.5 introduces more $\mathrm{NH}_{3}$ in the medium. The $\mathrm{NH}_{3}$ concentration in a range of $12 \mathrm{nM}$ to $5 \mu \mathrm{M}$ was calculated using the Henderson-Hasselbalch equation (Hütter, 1992), considering the temperature of $55^{\circ} \mathrm{C}$ at $\mathrm{pH} 3$ to 5.5, respectively. At pH 5.5, we measured a $\mathrm{NO}_{2}^{-}$concentration

TABLE 1 | Overview of $\mathrm{NH}_{4}^{+}$oxidation and $\mathrm{NO}_{2}^{-}$reduction rates calculated in each continuous culture at two different $\mathrm{pH}$ values.

\begin{tabular}{|c|c|c|c|c|}
\hline & \multicolumn{4}{|c|}{ Continuous cultures } \\
\hline & \multicolumn{2}{|c|}{$\mathrm{CH}_{4} / \mathrm{NH}_{4}^{+}$} & \multicolumn{2}{|c|}{$\mathrm{H}_{2} / \mathrm{NH}_{4}^{+}$} \\
\hline & pH 3 & pH 5.5 & pH 3 & pH 5.5 \\
\hline $\mathrm{NH}_{4}^{+}\left(\mathrm{NH}_{3}\right)^{\mathrm{a}}$ & $4(0.02)$ & $4(5)$ & $4(0.02)$ & $4(5)$ \\
\hline $\mathrm{NH}_{4}^{+}$oxidation ${ }^{\mathrm{b}}$ & $\mathrm{BDL}^{\mathrm{d}}$ & $N D^{e}$ & $0.12^{f}$ & 48.2 \\
\hline $\mathrm{NO}_{2}^{-}$reduction ${ }^{\mathrm{b}}$ & ND & ND & BDL & 0.8 \\
\hline $\mathrm{NO}_{2}^{-}$reduction ${ }^{\mathrm{bc}}$ & 0.015 & ND & 0.011 & 74.4 \\
\hline
\end{tabular}

${ }^{a} \mathrm{NH}_{4}^{+}$and $\mathrm{NH}_{3}$ concentrations are in $\mathrm{mM}$ and $\mu \mathrm{M}$, respectively.

${ }^{b} \mathrm{NO}_{2}^{-}$production and $\mathrm{N}_{2} \mathrm{O}$ production values are in $\mathrm{nmol} \cdot \mathrm{h}^{-1} \cdot \mathrm{mg} \mathrm{DW^{-1 }}$

${ }^{c} \mathrm{NO}_{2}^{-}$reduction rates under anoxic conditions.

${ }^{d} B D L$, below detection limit.

${ }^{e} N D$, not determined.

${ }^{f}$ All values are the average of two replicates of the same continuous culture with $<5 \%$ difference between duplicates. 


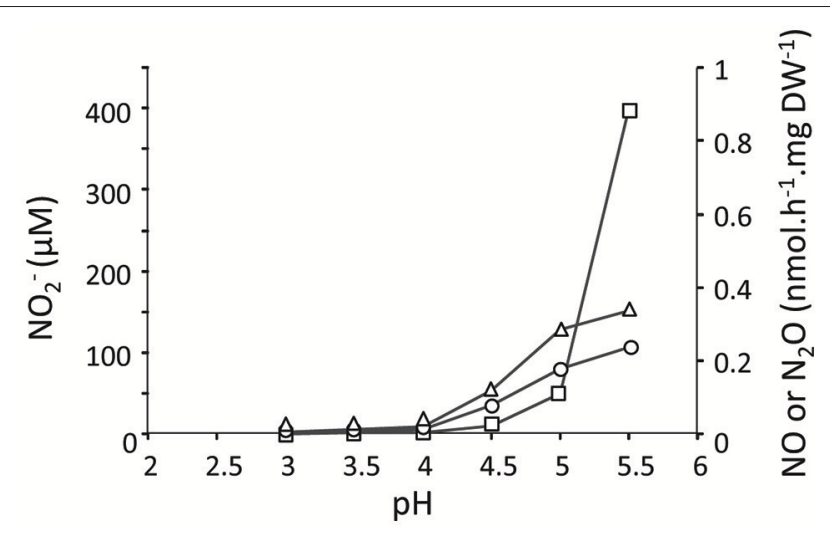

FIGURE 1 | The concentration of $\mathrm{NO}_{2}^{-}$(open rectangles) and production rates of $\mathrm{NO}$ (open triangles) and $\mathrm{N}_{2} \mathrm{O}$ (open circles) at pH values from 3 to 5.5 in the $\mathrm{H}_{2} / \mathrm{NH}_{4}^{+}$continuous culture (1.2 L; $D=0.023 \mathrm{~h}^{-1} ; \mathrm{OD}_{600}=0.85 ; \mathrm{O}_{2}$ limited; $4 \mathrm{mM} \mathrm{NH}_{4}^{+}$). The amounts of $\mathrm{NO}_{2}^{-}, \mathrm{NO}$ and $\mathrm{N}_{2} \mathrm{O}$ were determined when cells in the reactor reached the steady state. Each data point represents the average of two replicates with deviation of individual values below $5 \%$.

at steady state of about $420 \mu \mathrm{M}$ in the reactor (Figure 2) resulting from a production rate of $\approx 48 \mathrm{nmol} \mathrm{NO}_{2}^{-} \cdot \mathrm{h}^{-1} \cdot \mathrm{mg} \mathrm{DW}^{-1}$, while nitrite production at $\mathrm{pH} 3$ was very limited. Based on the clear effect of increasing $\mathrm{pH}$ on the production of $\mathrm{NO}_{2}^{-}$, one could speculate that the real substrate for $\mathrm{pMMO}$ to produce $\mathrm{NO}_{2}^{-}$is $\mathrm{NH}_{3}\left(\right.$ not $\mathrm{NH}_{4}^{+}$). Furthermore, the $\mathrm{NO}_{2}^{-}$reduction activities (NO and $\mathrm{N}_{2} \mathrm{O}$ production) were measured at $0.81 \mathrm{nmol} \mathrm{NO}_{2}^{-} \cdot \mathrm{h}^{-1} \cdot \mathrm{mg}$ $\mathrm{DW}^{-1}$ (1.7\% of $\mathrm{NH}_{4}^{+}$oxidation rate) which is 53 -fold higher than that in the $\mathrm{CH}_{4} / \mathrm{NH}_{4}^{+}$culture (Table 1). A rapid $\mathrm{NO}_{2}^{-}$ consumption $\left(\approx 83 \mathrm{nmol} \mathrm{NO}_{2}^{-} \cdot \mathrm{h}^{-1}\right.$. $\left.\mathrm{mg} \mathrm{DW}^{-1}\right)$ was observed when $\mathrm{O}_{2}$ supply was switched off completely (Figure 2 ), and the $\mathrm{NO}_{2}^{-}$reduction rate (as $\mathrm{NO}$ and $\mathrm{N}_{2} \mathrm{O}$ ) increased about 100-fold $\left(74.4 \mathrm{nmol} \mathrm{NO}_{2}^{-} \cdot \mathrm{h}^{-1} \cdot \mathrm{mg} \mathrm{DW}^{-1}\right)$. A rapid initial increase of $\mathrm{NO}$ suggests that conversion to $\mathrm{N}_{2} \mathrm{O}$ is the rate limiting step. The decrease of $\mathrm{N}_{2} \mathrm{O}$ levels was due to the continuous dilution of the gas present in the reactor headspace (total gas flow rate in the outlet $\approx 15 \mathrm{ml} \cdot \mathrm{min}^{-1}$ ). Concentrations of $1-5 \mu \mathrm{M} \mathrm{NH}_{2} \mathrm{OH}$ were measured in data points before and after switching off $\mathrm{O}_{2}$ supply.

We further tested the effect of different concentrations of $\mathrm{NH}_{4}^{+}(4-20 \mathrm{mM})$ on the $\mathrm{NO}_{2}^{-}, \mathrm{NO}$ and $\mathrm{N}_{2} \mathrm{O}$ production at $\mathrm{pH}$ 4 under oxygen limitation in the $\mathrm{H}_{2} / \mathrm{NH}_{4}^{+}$continuous culture (Figure 3). We showed that the concentrations of $\mathrm{NO}_{2}^{-}, \mathrm{NO}$, and $\mathrm{N}_{2} \mathrm{O}$ slightly increased once the $\mathrm{NH}_{4}^{+}$concentration was gradually elevated. This observation indicates that at $\mathrm{pH} 4$, even a 4-fold increase in the $\mathrm{NH}_{4}^{+}$concentration did not result in a high production of $\mathrm{NO}_{2}^{-}$similar to what we observed at $\mathrm{pH} 5.5$ supporting our assumption that $\mathrm{pH}$ plays an important role regarding the availability of $\mathrm{NH}_{3}$ molecules. Furthermore, we showed that the cells in the $\mathrm{CH}_{4} / \mathrm{NO}_{3}^{-}$continuous culture were able to perform $\mathrm{NO}_{2}^{-}$reduction at a rate of $120 \mathrm{nmol}$ $\mathrm{NO}_{2}^{-} \cdot \mathrm{h}^{-1}$.mg DW ${ }^{-1}$ by converting the added $\mathrm{NO}_{2}^{-}(50 \mu \mathrm{M})$ to $\mathrm{NO}$ and further to $\mathrm{N}_{2} \mathrm{O}$ in the absence of oxygen (Figure 4). Table 1 shows an overview of rates of ammonium oxidation to nitrite and nitrite reduction to $\mathrm{NO} / \mathrm{N}_{2} \mathrm{O}$ ) in the different continuous culture.

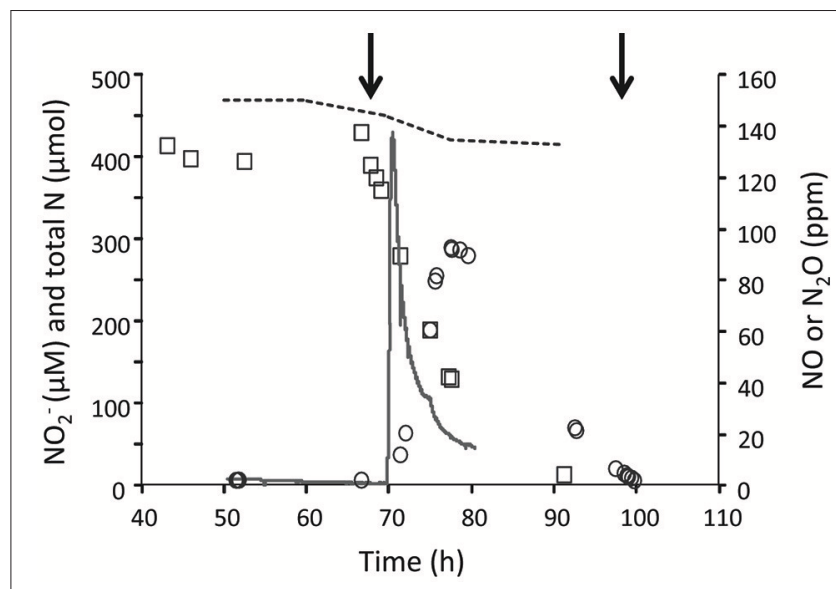

FIGURE 2 | The concentrations of $\mathrm{NO}_{2}^{-}, \mathrm{NO}$ and $\mathrm{N}_{2} \mathrm{O}$ in the $\mathrm{H}_{2} / \mathrm{NH}_{4}^{+}$ continuous culture at pH $5.5\left(1.2 \mathrm{~L} ; \mathrm{D}=0.023 \mathrm{~h}^{-1} ; \mathrm{OD}_{600}=0.85 ; \mathrm{O}_{2}\right.$ limited; $4 \mathrm{mM} \mathrm{NH}_{4}^{+}$). Nitrite (open rectangles), $\mathrm{NO}$ (solid line), $\mathrm{N}_{2} \mathrm{O}$ (open circles) were determined under $\mathrm{O}_{2}$ limitation and anoxic conditions. The first arrow indicates the oxic to anoxic, the second arrow indicates the anoxic to oxic condition and the dashed line shows the total $\mathrm{N}$ during the experimental phase. The decrease of $\mathrm{N}_{2} \mathrm{O}$ levels was because of the continuous dilution of the gas present in the reactor headspace (total gas flow rate in the outlet $\approx 15$ $\left.\mathrm{ml} \cdot \mathrm{min}^{-1}\right)$.

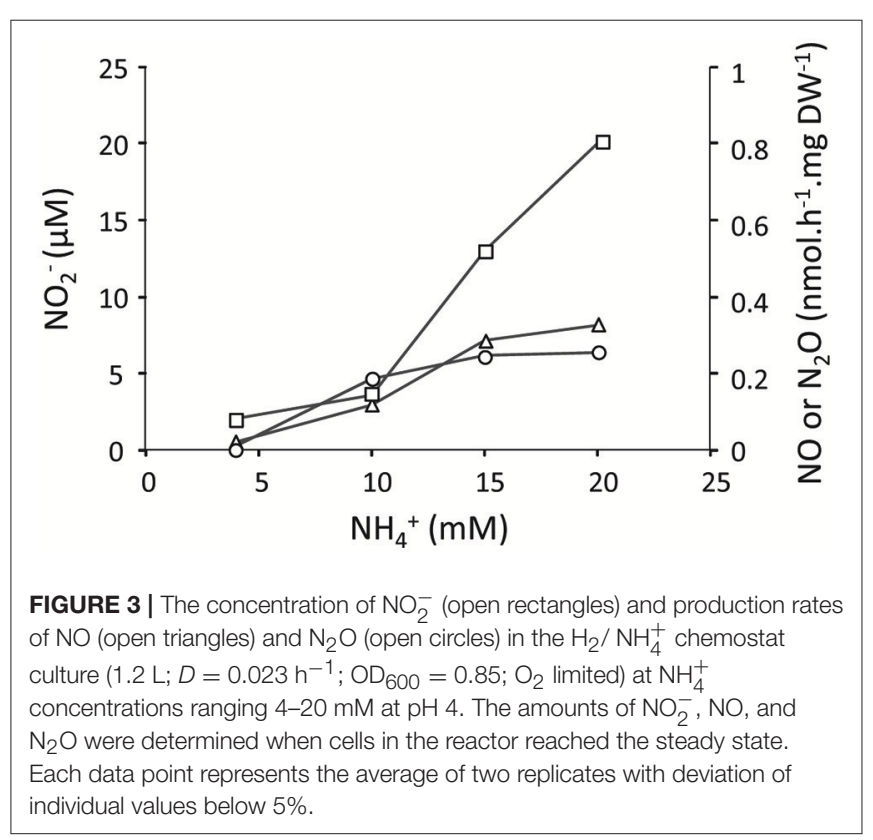

\section{Kinetics of Ammonia Oxidation}

The affinity constants $\left(\mathrm{K}_{\mathrm{s}}\right)$ for $\mathrm{NH}_{4}^{+}$and $\mathrm{NH}_{3}$ were determined using SolV cells from the $\mathrm{CH}_{4} / \mathrm{NO}_{3}^{-}$continuous culture. From the initial production rates of nitrite the best fitting curves to Michaelis-Menten kinetics were predicted (Figure S1). Since part of the $\mathrm{NH}_{4}^{+}$is present as $\mathrm{NH}_{3}$ at $\mathrm{pH} 6\left(1 \mathrm{M} \mathrm{NH}_{4}^{+}\right.$is about $3 \mathrm{mM}$ $\mathrm{NH}_{3}$ at $\mathrm{pH}$ 6), the Michaelis-Menten curves were also produced based on the $\mathrm{NH}_{3}$ concentrations (Figure S1). Therefore, we 


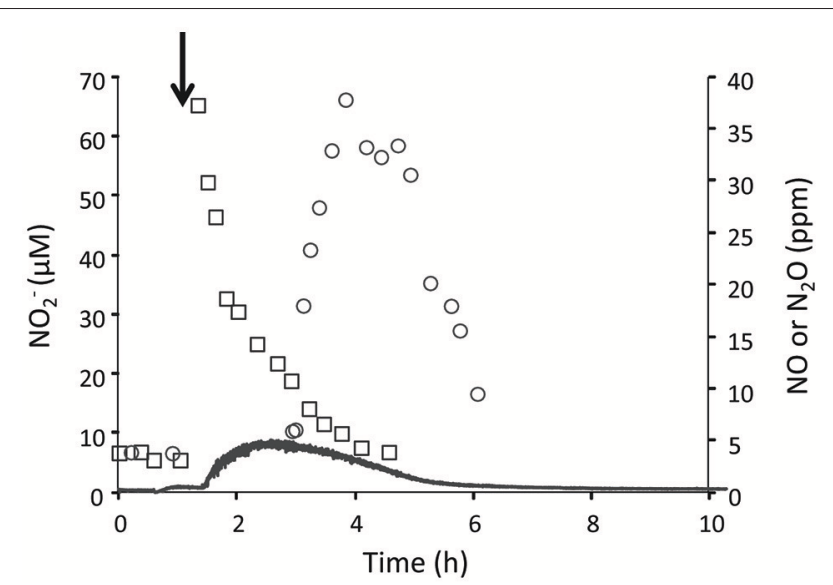

FIGURE 4 | Cells from the $\mathrm{CH}_{4} / \mathrm{NO}_{3}^{-}$continuous culture (0.6 L; $D=$

$0.026 \mathrm{~h}^{-1} ; \mathrm{OD}_{600}=1.3 ; \mathrm{O}_{2}$ limited) perform denitrification when nitrite was added to the reactor vessel. The concentrations of $\mathrm{NO}_{2}^{-}$(open rectangles), $\mathrm{NO}$ (solid line) and $\mathrm{N}_{2} \mathrm{O}$ (open circles) were measured before and after addition of $50 \mu \mathrm{M} \mathrm{NO}_{2}^{-}$(arrow). Duplicates of individual values do not deviate more than 5 and $10 \%$ for $\mathrm{NO}_{2}^{-}$and $\mathrm{N}_{2} \mathrm{O}$, respectively.

calculated apparent affinity constants $\left(\mathrm{K}_{\mathrm{s}}\right)$ for both $\mathrm{NH}_{4}^{+}$and $\mathrm{NH}_{3}$ in strain SolV (Table 2).

To identify the type of inhibition, the Michaelis-Menten curves were transformed to Lineweaver-Burk plots. Figure S2 shows a set of double reciprocal plots, obtained with different $\mathrm{NH}_{4}^{+}$concentrations in the presence of $\mathrm{CH}_{4}$ at a range of 2 , 4 , and $8 \%(\mathrm{v} / \mathrm{v})$. Increasing the $\mathrm{CH}_{4}$ concentration resulted in a group of lines with a common intercept on the $1 / \mathrm{V}_{0}$ axis but with different slopes. The intercept is $1 / \mathrm{V}_{\max }$ and $\mathrm{V}_{\max }$ is constant regardless of increasing $\mathrm{CH}_{4}$ concentration $\left(\mathrm{V}_{\max }=\right.$ $1.61 \pm 0.05 \mu \mathrm{mol}^{-1} \mathrm{~h}^{-1} . \mathrm{mg}$ protein $\left.{ }^{-1}\right)$. The constant intercept of all lines suggests a competitive inhibition between $\mathrm{CH}_{4}$ and $\mathrm{NH}_{3}$. The $\mathrm{NO}_{2}^{-}$production rate in the absence of $\mathrm{CH}_{4}$ was about 3- to 4 -fold lower compared to the rate in the presence of $0.5 \%(\mathrm{v} / \mathrm{v}) \mathrm{CH}_{4}$ suggesting that traces of $\mathrm{CH}_{4}$ are essential for the pMMO activation. Table 2 shows an overview of affinity constants calculated for $\mathrm{NH}_{3}\left(\mathrm{NH}_{4}^{+}\right)$obtained in the incubations with different $\mathrm{CH}_{4}$ concentrations. Affinity constants for $\mathrm{NH}_{3}$ were calculated based on the Henderson-Hasselbalch equation considering a temperature of $55^{\circ} \mathrm{C}$ (Hütter, 1992). These results showed that increasing $\mathrm{CH}_{4}$ concentration limits the affinity of pMMO for $\mathrm{NH}_{3}$ significantly, which correlates with the observed competitive inhibition between $\mathrm{CH}_{4}$ and $\mathrm{NH}_{3}$.

\section{Whole Genome Transcriptome Analysis of Strain SolV}

Expression levels of housekeeping genes and genes involved in metabolism of nitrogenous compounds were determined for $\mathrm{H}_{2}$ and $\mathrm{CH}_{4}$-grown cells (both under $\mathrm{O}_{2}$ limited conditions). These values were compared to the expression values in cells growing at $\mu_{\max }$ on $\mathrm{CH}_{4}$ (without limitation). To compare baseline expression levels, we selected a group of 384 housekeeping genes (in total $437.9 \mathrm{kbp}$ ) involved in energy generation, ribosome
TABLE 2 | Kinetics of $\mathrm{NH}_{4}^{+}$oxidation with variable $\mathrm{CH}_{4}$ supply at $\mathrm{pH} 6$.

\begin{tabular}{|c|c|c|c|}
\hline \multirow[t]{2}{*}{$\mathrm{CH}_{4}$} & \multicolumn{2}{|c|}{ Affinity constant ${ }^{\mathrm{c}}\left[\mathrm{K}_{\mathrm{s}(\mathrm{app})}\right]$} & \multirow[t]{2}{*}{$V_{\max }{ }^{d}$} \\
\hline & $\mathrm{NH}_{4}^{+}(\mathrm{mM})$ & $\mathrm{NH}_{3}(\mu \mathrm{M})$ & \\
\hline $0.5^{\mathrm{a}}(0.005)^{\mathrm{b}}$ & 1.25 & 4.9 & 1.61 \\
\hline $1(0.01)$ & 1.50 & 5.8 & 1.61 \\
\hline $2(0.02)$ & 6 & 23.3 & 1.43 \\
\hline $3(0.03)$ & 9 & 35.0 & 1.43 \\
\hline $4(0.04)$ & 30 & 116.7 & 1.43 \\
\hline $8(0.08)$ & 70 & 272.3 & 1.43 \\
\hline
\end{tabular}

${ }^{a} \mathrm{CH}_{4}$ concentrations in \% ( $\left.\mathrm{V} / \mathrm{V}\right)$.

${ }^{b} \mathrm{CH}_{4}$ concentrations in the liquid in $\mathrm{mM}$.

${ }^{c}$ Affinity constants were calculated based on two independent experiments

${ }^{d} V_{\text {max }}$ values are in $\mu \mathrm{mol} \mathrm{NO}_{2}^{-} \cdot h^{-1} \cdot \mathrm{mg}_{\text {protein }}{ }^{-1}$.

assembly, carbon fixation (CBB cycle), C1 metabolism (except for pmo), amino acid synthesis, cell wall synthesis, translation, transcription, DNA replication, and tRNA synthesis (Khadem et al., 2012a,b). All ratios of expression levels of the housekeeping genes under these conditions were between 0.5 and 2 (Table S1). The robustness of the transcriptome data were tested using the method of Chaudhuri et al. (2011). In this method, the logarithmic value of RPKM +1 of each condition (in duplicates) was calculated and the values were plotted against each other. This resulted in correlation coefficients of $0.80,0.82$, and 0.87 (Figure S3), showing the high robustness of the transcriptome data.

The transcriptome data showed that genes encoding the enzymes involved in $\mathrm{NH}_{4}^{+}$assimilation in strain SolV including glutamine synthase $(\mathrm{Gln} A)$ /glutamate synthase (GltB) and the alanine and glutamate dehydrogenases (Ald, Gdh) were equally expressed under all conditions (Table 3). Among these genes, only $g \ln A$ was about 2.5 -fold less expressed in the continuous cultures compared to the cells grown at $\mu_{\max }$ (Table 3 ). We also found that the $c a r A B$ operons (encoding the glutamine hydrolyzing carbamoyl-phosphate synthase) were constitutively expressed. The conversion of glutamine and carbon dioxide into glutamate and carbamoyl phosphate is performed by this enzyme (Khadem et al., 2012a). Similarly, the $\operatorname{argDHFG}$ operons (encoding enzymes from the urea cycle) were expressed under all conditions. Interestingly, we detected the ammonium/ammonia transporter $(a m t B)$ was at least 3 -fold up-regulated in the $\mathrm{CH}_{4} / \mathrm{NO}_{3}^{-}$continuous culture compared to the other conditions reflecting that cells may have a preference for $\mathrm{NH}_{4}^{+}$as $\mathrm{N}$ source. In addition, the genes encoding the $\mathrm{NO}_{3}^{-} / \mathrm{NO}_{2}^{-}$transport (nas $A)$ and the assimilatory nitrite and nitrate reductases were 9- to 45 -fold up-regulated in the $\mathrm{CH}_{4} / \mathrm{NO}_{3}^{-}$continuous culture compared to the cells at $\mu_{\max }$ (Table 3 ). Both latter observations correlate with the fact that nitrate was used as $\mathrm{N}$-source under this condition. Interestingly, the transcriptome analysis showed that the nirK and nor $C$ genes were up-regulated in the chemostat continuous culture compared to those at $\mu_{\max }$, while results for norB (encoding the catalytic subunit) were less clear. This may imply that other $\mathrm{NO}$ reductases were active. We also found that the hao $A$ gene was about 2-fold down-regulated in the $\mathrm{CH}_{4} / \mathrm{NO}_{3}^{-}$ 
TABLE 3 | The transcriptome analysis of the genes involved in nitrogen metabolism in Methylacidiphilum fumariolicum SolV.

\begin{tabular}{|c|c|c|c|c|c|}
\hline \multirow[t]{2}{*}{ Enzyme } & \multirow[t]{2}{*}{ Gene name } & \multirow[t]{2}{*}{ GenBank identifier } & \multicolumn{3}{|c|}{ Expression level (RPKM)a } \\
\hline & & & $\mathrm{H}_{2} / \mathrm{NH}_{4}^{+}$ & $\mathrm{CH}_{4} / \mathrm{NO}_{3}^{-}$ & Cells at $\mu_{\text {max }}{ }^{b}$ \\
\hline Glutamine synthetase type I (EC 6.3.1.2) & $g \ln A$ & Mfumv2_1420 & 764 & 893 & 2,065 \\
\hline Glutamine synthetase regulatory protein PII & $g \ln B$ & Mfumv2_1419 & 943 & 719 & 883 \\
\hline [Protein-PII] uridylyltransferase (EC 2.7.7.59) & $g \ln D$ & Mfumv2_1837 & 124 & 136 & 156 \\
\hline Nitrogen regulatory protein PII & $g \ln K$ & Mfumv2_1285 & 371 & 125 & 193 \\
\hline Alanine dehydrogenase (EC 1.4.1.1) & ald & Mfumv2_2049 & 107 & 106 & 171 \\
\hline Glutamate dehydrogenase (EC 1.4.1.2; EC 1.4.1.4) & $g d h A$ & Mfumv2_0663 & 227 & 231 & 421 \\
\hline Glutamate synthase [NADPH] large chain (EC 1.4.1.13) & $g / t B$ & Mfumv2_2397 & 906 & 696 & 1,300 \\
\hline Glutamate synthase beta chain & gltD & Mfumv2_1978 & 192 & 328 & 198 \\
\hline Ornithine-acetylornithine aminotransferase (EC 2.6.1.11) & $\arg D 1$ & Mfumv2_1148 & 279 & 271 & 627 \\
\hline Ornithine-acetylornithine aminotransferase (EC 2.6.1.11) & $\arg D 2$ & Mfumv2_0135 & 145 & 273 & 357 \\
\hline Argininosuccinate lyase (EC 4.3.2.1) & $\operatorname{argH}$ & Mfumv2_2465 & 78 & 68 & 203 \\
\hline Ornithine carbamoyltransferase (EC 2.1.3.3) & $\arg F$ & Mfumv2_0136 & 161 & 239 & 278 \\
\hline Argininosuccinate synthase (EC 6.3.4.5) & $\arg G$ & Mfumv2_1907 & 666 & 654 & 645 \\
\hline Carbamoyl-phosphate synthase small chain (EC 6.3.5.5) & carA & Mfumv2_1926 & 318 & 350 & 453 \\
\hline Carbamoyl-phosphate synthase large chain (EC 6.3.5.5) & carB & Mfumv2_0408 & 347 & 674 & 514 \\
\hline Ammonium-Ammonia transporter & $a m t B$ & Mfumv2_1275 & 294 & 1,082 & 391 \\
\hline Nitrate ABC transporter, nitrate-binding protein & $\operatorname{tau} A$ & Mfumv2_1299 & 28 & 41 & 34 \\
\hline Assimilatory nitrate reductase catalytic subunit (EC 1.7.99.4) & nasC & Mfumv2_1297 & 20 & 105 & 13 \\
\hline Nitrate-nitrite transporter & nasA & Mfumv2_1294 & 67 & 321 & 23 \\
\hline Nitrite reductase $[\mathrm{NAD}(\mathrm{P}) \mathrm{H}]$ large subunit (EC 1.7.1.4) & $\operatorname{nir} B$ & Mfumv2_1296 & 140 & 854 & 19 \\
\hline Nitrite reductase $[\mathrm{NAD}(\mathrm{P}) \mathrm{H}]$, small subunit (EC 1.7.1.4) & $\operatorname{nir} D$ & Mfumv2_1295 & 63 & 308 & 33 \\
\hline Signal transduction histidine kinase with PAS domain & $n t r B$ & Mfumv2_0271 & 275 & 180 & 291 \\
\hline Signal transduction response regulator, NtrC family & ntrC1 & Mfumv2_1349 & 98 & 84 & 103 \\
\hline Sigma-54 dependent transcriptional regulator-response regulator & ntrC2 & Mfumv2_1221 & 65 & 59 & 100 \\
\hline Transcriptional regulator, NifA subfamily, Fis Family & ntrC3 & Mfumv2_2103 & 581 & 400 & 533 \\
\hline Sigma-54 dependent transcriptional regulator-response regulator & ntrC4 & Mfumv2_0272 & 264 & 387 & 293 \\
\hline Hydroxylamine dehydrogenase (EC 1.7.2.6) & haoA & Mfumv2_2472 & 402 & 109 & 351 \\
\hline Hydroxylamine dehydrogenase associated protein & haoB & Mfumv2_2471 & 179 & 163 & 302 \\
\hline Nitric-oxide reductase subunit B (EC 1.7.99.7) & norB & Mfumv2_0037 & 125 & 84 & 178 \\
\hline Nitric-oxide reductase subunit C (EC 1.7.99.7) & norC & Mfumv2_0036 & 429 & 372 & 197 \\
\hline Copper-containing nitrite reductase (EC 1.7.2.1) & nirk & Mfumv2_1973 & 379 & 520 & 136 \\
\hline DNA-binding response regulator, NarL family & $m \times a B$ & Mfumv2_1738 & 163 & 291 & 288 \\
\hline DNA-binding response regulator, LuxR family & citB1 & Mfumv2_1799 & 7,016 & 4,126 & 1,063 \\
\hline DNA-binding response regulator, LuxR family & citB2 & Mfumv2_0457 & 137 & 133 & 307 \\
\hline
\end{tabular}

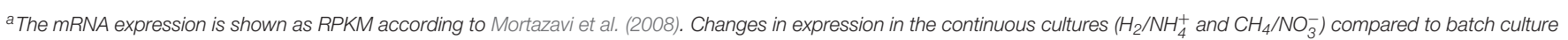
cells growing at $\mu_{\max }$ are demonstrated by shading [up-regulation $>2$-fold dark gray; down-regulation $<0.5$ (light gray)].

${ }^{b}$ Cells grown on $\mathrm{CH}_{4}$ with $\mathrm{NH}_{4}^{+}$as $\mathrm{N}$-source.

continuous culture compared to the $\mathrm{H}_{2} / \mathrm{NH}_{4}^{+}$and $\mu_{\max }$ cultures, likely due to the absence of $\mathrm{NH}_{4}^{+}$in this condition. The haoA gene showed comparable high expression levels in the $\mathrm{H}_{2} / \mathrm{NH}_{4}^{+}$ continuous and batch $\mu_{\max }$ culture (Table 3 ).

The transcriptome data showed different expression levels of two of the three different pmo operons in strain SolV (Table 4). We found that the pmoCAB2 operon including the mfumv2_1793, mfumv2_1792 and mfumv2_1791 subunits was significantly expressed (RPKM values 14,899-37,218) in the cells growing at $\mu_{\max }$ with no limitation and the pmoCAB1 operon showed very low expression. In contrast, cells in the continuous cultures on $\mathrm{H}_{2} / \mathrm{NH}_{4}^{+}$and $\mathrm{CH}_{4} / \mathrm{NO}_{3}^{-}$under $\mathrm{O}_{2}$ limitation showed a significantly different expression pattern of the pmoCAB operons. We found that the pmoCAB1 operon including mfumv2_1796, mfumv2_1795 and mfumv2_1794 subunits was very highly expressed under these conditions (RPKM values $5,003-47,785)$, whereas the expression levels of the pmoCAB2 operon was found to be 2- to 19-fold lower in comparison to the cells growing at $\mu_{\max }$. The pmoCAB3 operon including the mfumv2_1606, mfumv2_1605 and mfumv2_1604 subunits showed low expressed under all conditions although expression in $\mathrm{H}_{2} / \mathrm{NH}_{4}^{+}$grown cells seems to be slightly up-regulated. The conversion of methanol to formaldehyde is the second step in $\mathrm{CH}_{4}$ oxidation pathway. Interestingly, it has been shown 
TABLE 4 | The transcriptome analysis of the genes involved in the methane oxidation pathway of Methylacidiphilum fumariolicum SolV.

\begin{tabular}{|c|c|c|c|c|c|}
\hline \multirow[t]{2}{*}{ Enzyme } & \multirow[t]{2}{*}{ Gene name } & \multirow[t]{2}{*}{ GenBank identifier } & \multicolumn{3}{|c|}{ Expression level (RPKM) ${ }^{a}$} \\
\hline & & & $\mathrm{H}_{2} / \mathrm{NH}_{4}^{+}$ & $\mathrm{CH}_{4} / \mathrm{NO}_{3}^{-}$ & Cells at $\mu_{\text {max }}{ }^{b}$ \\
\hline \multirow[t]{3}{*}{ Particulate $\mathrm{CH}_{4}$ monooxygenase_1 (EC 1.14.13.25) } & pmoC1 & Mfumv2_1796 & 47,785 & 34,734 & 207 \\
\hline & pmoA1 & Mfumv2_1795 & 9,772 & 3,775 & 41 \\
\hline & pmoB1 & Mfumv2_1794 & 9,550 & 5,003 & 164 \\
\hline \multirow[t]{3}{*}{ Particulate $\mathrm{CH}_{4}$ monooxygenase_2 (EC 1.14.13.25) } & pmoC2 & Mfumv2_1793 & 18,136 & 5,462 & 37,218 \\
\hline & pmoA2 & Mfumv2_1792 & 2,383 & 1,119 & 21,207 \\
\hline & pmoB2 & Mfumv2_1791 & 2,139 & 1,265 & 14,899 \\
\hline \multirow[t]{3}{*}{ Particulate $\mathrm{CH}_{4}$ monooxygenase_3 (EC 1.14.13.25) } & pmoC3 & Mfumv2_1606 & 539 & 209 & 181 \\
\hline & pmoA3 & Mfumv2_1605 & 143 & 17 & 57 \\
\hline & pmoB3 & Mfumv2_1604 & 58 & 13 & 28 \\
\hline Methanol dehydrogenase XoxF-type (EC 1.1.99.8) & XOXF & Mfumv2_1183 & 6,220 & 5,291 & 6,041 \\
\hline Extracellular solute-binding protein family 3 & $x O x J$ & Mfumv2_1184 & 714 & 1,057 & 1,478 \\
\hline Cytochrome c1 protein fused with XoxJ & xOXGJ & Mfumv2_1185 & 611 & 829 & 1,042 \\
\hline Coenzyme PQQ precursor peptide & ppqA & Mfumv2_1461a & 2,920 & 1,919 & 2,133 \\
\hline \multirow[t]{6}{*}{ Coenzyme PQQ synthesis proteins } & $p q q B$ & Mfumv2_1461 & 1,308 & 588 & 620 \\
\hline & $p q q C$ & Mfumv2_1462 & 1,165 & 560 & 622 \\
\hline & $p q q D$ & Mfumv2_0766 & 144 & 242 & 60 \\
\hline & $p q q D$ & Mfumv2_1463 & 451 & 153 & 249 \\
\hline & $p q q E$ & Mfumv2_1464 & 747 & 514 & 509 \\
\hline & $p q q F$ & Mfumv2_0519 & 408 & 680 & 718 \\
\hline \multirow[t]{3}{*}{ NADPH:quinone oxidoreductase (EC 1.6.5.5) } & qor1 & Mfumv2_1937 & 253 & 287 & 315 \\
\hline & qor2 & Mfumv2_2088 & 338 & 300 & 432 \\
\hline & qor3 & Mfumv2_0618 & 60 & 12 & 130 \\
\hline \multirow[t]{2}{*}{ Zn-dependent alcohol dehydrogenase (EC 1.1.1.1) } & adh1 & Mfumv2_2176 & 160 & 154 & 208 \\
\hline & adh2 & Mfumv2_0724 & 252 & 218 & 288 \\
\hline \multirow[t]{2}{*}{ Aldehyde dehydrogenase (EC 1.2.1.3) } & dhaS1 & Mfumv2_2408 & 130 & 317 & 108 \\
\hline & dhaS2 & Mfumv2_0597 & 1,310 & 1,503 & 1,125 \\
\hline \multirow[t]{2}{*}{ Dihydropteroate synthase (EC 2.5.1.15) } & folP1 & Mfumv2_0503 & 161 & 233 & 167 \\
\hline & folP2 & Mfumv2_2400 & 126 & 95 & 208 \\
\hline Formate-tetrahydrofolate ligase (EC 6.3.4.3) & fhs & Mfumv2_2082 & 396 & 457 & 282 \\
\hline $\begin{array}{l}\text { Methylenetetrahydrofolate dehydrogenase (NADP+) (EC 1.5.1.5) - } \\
\text { methenyltetrahydrofolate cyclohydrolase (EC 3.5.4.9) }\end{array}$ & folD & Mfumv2_1033 & 257 & 173 & 261 \\
\hline GTP cyclohydrolase I (EC 3.5.4.16) type 2 & folE & Mfumv2_0074 & 1,485 & 1,477 & 795 \\
\hline NAD-dependent formate dehydrogenase alpha subunit & $f d s A$ & Mfumv2_1457 & 568 & 665 & 1,342 \\
\hline NAD-dependent formate dehydrogenase beta subunit & $f d s B$ & Mfumv2_1458 & 569 & 435 & 1,149 \\
\hline NAD-dependent formate dehydrogenase gamma subunit & $f d s C$ & Mfumv2_1459 & 475 & 240 & 672 \\
\hline NAD-dependent formate dehydrogenase delta subunit & $f d s D$ & Mfumv2_1456 & 593 & 979 & 588 \\
\hline NAD-dependent formate dehydrogenase (EC 1.2.1.2) & $f d h$ & Mfumv2_1567 & 738 & 863 & 1,110 \\
\hline Methylamine dehydrogenase light chain (EC 1.4.99.3) & $\operatorname{mau} A$ & Mfumv2_0350 & 119 & 450 & 108 \\
\hline Methylamine dehydrogenase heavy chain (EC 1.4.99.3) & mauB & Mfumv2_0347 & 99 & 135 & 235 \\
\hline
\end{tabular}

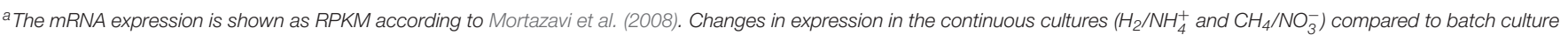
cells growing at $\mu_{\max }$ are demonstrated by shading [up-regulation $>2$-fold (dark gray), down-regulation $<0.5$ (light gray)].

${ }^{b}$ Cells grown on $\mathrm{CH}_{4}$ with $\mathrm{NH}_{4}^{+}$as $\mathrm{N}$-source.

that strain SolV contains a XoxF-type methanol dehydrogenase $(\mathrm{MDH})$ that can convert methanol directly to formate (Pol et al., 2014). We found that the $x o x F G J$ operon encoding the methanol dehydrogenase and $p q q A B C D E F$ operon encoding the proteins involved in biosynthesis of the methanol dehydrogenase cofactor pyrroloquinoline quinone were expressed more or less similar under all conditions tested. The last step of the $\mathrm{CH}_{4}$ oxidation pathway is conversion of formate to $\mathrm{CO}_{2}$ catalyzed by NADdependent formate dehydrogenase and a membrane-bound formate dehydrogenase. The genes encoding these enzymes were expressed under all conditions, although the expression levels of these enzymes (except for $f d s D$ and $f d h$ ) in continuous cultures under $\mathrm{O}_{2}$ limitation was 2- to 2.5-fold lower compared to cells grown at $\mu_{\max }$ (Table 4). 


\section{DISCUSSION}

In the present study, the physiological data of the $\mathrm{H}_{2} / \mathrm{NH}_{4}^{+}$ continuous culture showed that strain SolV is able to oxidize $\mathrm{NH}_{4}^{+}$to $\mathrm{NO}_{2}^{-}$at a rate of $48.2 \mathrm{nmol} \mathrm{NO}-\mathrm{h}^{-1} \cdot \mathrm{mg} \mathrm{DW}^{-1}$ at $\mathrm{pH}$ 5.5. At $\mathrm{pH} 3$, with less $\mathrm{NH}_{3}$ available this rate was about 400 -fold lower (Table 1). We also detected a very limited $\mathrm{NH}_{4}^{+}$oxidation rate in the cells of the $\mathrm{CH}_{4} / \mathrm{NH}_{4}^{+}$chemostat in comparison to the $\mathrm{H}_{2} / \mathrm{NH}_{4}^{+}$cells. These observations indicate that the higher $\mathrm{NH}_{4}^{+}$oxidation activity occurs when $\mathrm{CH}_{4}$ is replaced by $\mathrm{H}_{2}$ as the electron donor. Nitrification was previously reported in methanotrophs. $\mathrm{CH}_{4}$-dependent nitrification was detected in a humisol that was enriched with $\mathrm{CH}_{4}$ (Megraw and Knowles, 1987). It has been shown that methanotrophs are efficient nitrifiers and produce $\mathrm{NH}_{2} \mathrm{OH}$ as a product of $\mathrm{NH}_{3}$ monooxygenation (Bédard and Knowles, 1989; Nyerges and Stein, 2009).

We observed a similar pattern in the batch experiments using cells from the $\mathrm{CH}_{4} / \mathrm{NO}_{3}^{-}$continuous culture. In these batch tests, we found higher $\mathrm{NO}_{2}^{-}$production rates when the $\mathrm{CH}_{4}$ concentration was limited, although traces of $\mathrm{CH}_{4}$ seemed to be essential for activation of pMMO. In these batch tests, the calculated apparent affinity constants $\left[\mathrm{K}_{\mathrm{s}(\mathrm{app})}\right]$ for $\mathrm{NH}_{4}^{+}$were approximately between 1.25 and $70 \mathrm{mM}$. At increasing $\mathrm{pH}$ values the equilibrium shifts toward higher $\mathrm{NH}_{3}$ concentrations and the calculated $\mathrm{K}_{\mathrm{s}}$ values for $\mathrm{NH}_{3}$ in the same tests were 4-273 $\mu \mathrm{M}$. Comparable values have been reported in literature (Table 5). Our data showed that increasing the $\mathrm{pH}$ from 3 to 5.5 significantly affects the rates of $\mathrm{NH}_{4}^{+}$ oxidation to $\mathrm{NO}_{2}^{-}$. This reflects the fact that the pMMO of strain SolV might use $\mathrm{NH}_{3}$ as a substrate (and not $\mathrm{NH}_{4}^{+}$). This assumption could explain why at low $\mathrm{pH}$, when $\mathrm{NH}_{4}^{+}$ is present, we observed very limited nitrification. In a study from O'Neill and Wilkinson (1977), they also showed that by increasing $\mathrm{pH}$ the rate of $\mathrm{NH}_{4}^{+}$oxidation by $M$. trichosporium $\mathrm{OB} 3 \mathrm{~B}$ increased, and they also suggested the active species to be $\mathrm{NH}_{3}$.

In the present study, we showed that strain SolV performs $\mathrm{NO}_{2}^{-}$reduction to $\mathrm{N}_{2} \mathrm{O}$ usingcells from $\mathrm{CH}_{4} / \mathrm{NH}_{4}^{+}$and $\mathrm{H}_{2} / \mathrm{NH}_{4}^{+}$ continuous cultures (Table 1). Under anoxic condition, higher $\mathrm{NO}_{2}^{-}$reduction rates were observed in cells from the $\mathrm{CH}_{4} / \mathrm{NO}_{3}^{-}$ and $\mathrm{H}_{2} / \mathrm{NH}_{4}^{+}$cultures (Table 1). The reduction of $\mathrm{NO}_{2}^{-}$to
$\mathrm{N}_{2} \mathrm{O}$ may provide a way to remove potentially toxic $\mathrm{NO}_{2}^{-}$. The lower $\mathrm{NO}_{2}^{-}$reduction rate in $\mathrm{H}_{2} / \mathrm{NH}_{4}^{+}$compared to the $\mathrm{CH}_{4} / \mathrm{NO}_{3}^{-}$continuous cultures in the absence of oxygen could be explained by the fact that cells in the $\mathrm{H}_{2}$ reactor were confronted with $\mathrm{NH}_{2} \mathrm{OH}$ and $\mathrm{NO}_{2}^{-}$over a relatively long term. Cells might suffer under these conditions and show a decrease in $\mathrm{NO}_{2}^{-}$reduction rate. Many methanotrophs possess partial denitrification pathways and they are able to reduce $\mathrm{NO}_{2}^{-}$to $\mathrm{N}_{2} \mathrm{O}$ via NO (Nyerges et al., 2010; Campbell et al., 2011). Recently, two methanotrophic strains were cultured together (Methylomicrobium album ATCC 33003 and Methylocystis sp. strain ATCC 49242), one with high tolerance to $\mathrm{NH}_{4}^{+}$and one with high tolerance to $\mathrm{NO}_{2}^{-}$, and the nitrite-tolerant strain was shown to be more competitive and produced more $\mathrm{N}_{2} \mathrm{O}$ compared to the other strain (Nyerges et al., 2010). The highest $\mathrm{N}_{2} \mathrm{O}$ production rate was reported at about $0.4 \mathrm{nmol} \cdot \mathrm{h}^{-1}$ per $10^{6}$ cells in M. album ATCC 33003 (Nyerges et al., 2010). Campbell et al. (2011) reported a headspace production of $26.3 \mu \mathrm{M}$ $\mathrm{N}_{2} \mathrm{O}$ after $48 \mathrm{~h}\left(\approx 0.24 \mathrm{ppb} \cdot \mathrm{h}^{-1}\right.$ per $10^{6}$ cells $)$ in Methylococcus capsulatus Bath. Recently, Kits et al. (2015) reported the reduction of nitrate coupled to aerobic $\mathrm{CH}_{4}$ oxidation under extreme oxygen limited conditions in which $\mathrm{N}_{2} \mathrm{O}$ production $\left(0.414 \mu \mathrm{mol} . \mathrm{h}^{-1} . \mathrm{L}^{-1}\right)$ was directly supported by $\mathrm{CH}_{4}$ oxidation in $M$. denitrificans strain FJG1T. The latter $\mathrm{N}_{2} \mathrm{O}$ production rate is about 60 -fold lower compared to our results obtained under anoxic condition in the absence of $\mathrm{CH}_{4}$.

In this study, the transcriptome data showed that the pmoCAB1 and pmoCAB2 operons were tightly regulated by oxygen as observed previously (Khadem et al., 2012a). Recently, the down-regulation of $p m o C A B$ gene was detected in response to $30 \mathrm{mM} \mathrm{NH}_{4}^{+}$concentration in the medium compared to $10 \mathrm{mM} \mathrm{NO}_{3}^{-}$in Methylocystis sp. strain SC2 (Dam et al., 2014). It has been shown that $\mathrm{CH}_{4}$ oxidation in Methylocystis sp. strain SC2 cells supplied with $30 \mathrm{mM}$ $\mathrm{NH}_{4}^{+}$was inhibited at $\mathrm{CH}_{4}$ concentrations $<400 \mathrm{ppm}(\mathrm{v} / \mathrm{v}$; Dam et al., 2014). Our results in all cases showed no expression of the pmoCAB3 operon, suggesting other growth conditions could be examined to elucidate the regulation and role of this pmo operon. Recently, the concurrent growth of the methanotroph Methylocella silvestris was described on $\mathrm{CH}_{4}$ and propane (Crombie and Murrell, 2014). Two soluble di-iron center monooxygenase gene clusters (sMMO)

TABLE 5 | Comparison of apparent $\mathrm{K}_{\mathrm{S}}$ values for $\mathrm{NH}_{4}^{+}$.

\begin{tabular}{|c|c|c|c|c|c|}
\hline Organism & $\mathrm{K}_{\mathrm{s}}\left(\mathrm{NH}_{4}^{+}\right) \mathrm{mM}$ & $\mathrm{CH}_{4} \%(\mathrm{v} / \mathrm{v})$ & $\mathrm{pH}$ & Calculated $\mathrm{K}_{s}\left(\mathrm{NH}_{3}\right) \mu \mathrm{M}$ & References \\
\hline M. fumariolicum & $1.25-70$ & $0.5-8$ & 6 & $4-273$ & This study ${ }^{a}$ \\
\hline Methylocystis sp. & 0.5 and 1.1 & 0.5 and 5 & - & - & Nyerges and Stein, 2009 \\
\hline \multirow[t]{2}{*}{ Ms. trichosporium } & 4.1 & - & 6.5 & - & O'Neill and Wilkinson, 1977 \\
\hline & 0.6 & - & 7.5 & - & \\
\hline
\end{tabular}


were identified with different expression during bacterial growth on these alkanes, although both gene sets were essential for efficient propane utilization (Crombie and Murrell, 2014).

In our study, the hao $A B$ genes encoding hydroxylamine dehydrogenase (HAO) and an associated protein were constitutively expressed in cells grown in the $\mathrm{H}_{2} / \mathrm{NH}_{4}^{+}$ continuous and batch cultures (Table 3). In M. capsulatus Bath the hao $A B$ genes were shown to respond to addition of $5 \mathrm{mM}$ of $\mathrm{NH}_{4}^{+}$(Poret-Peterson et al., 2008). The currently accepted model for oxidation of $\mathrm{NH}_{3}$ to $\mathrm{NO}_{2}^{-}$proceeds via the intermediate $\mathrm{NH}_{2} \mathrm{OH}$ which in a follow up reaction catalyzed by $\mathrm{HAO}$ is oxidized to $\mathrm{NO}_{2}^{-}$. Recently, evidence was provided that $\mathrm{HAO}$ oxidizes $\mathrm{NH}_{2} \mathrm{OH}$ by only three electrons to $\mathrm{NO}$ under both aerobic and anaerobic conditions using purified Nitrosomonas europaea HAO (Caranto and Lancaster, 2017). This also implies the need for an enzyme converting $\mathrm{NO}$ to $\mathrm{NO}_{2}^{-}$. For future research we aim at purifying the HAO from strain SolV to test its properties.

The assimilatory nitrite and nitrate reductase genes were found 9- to 45-fold up-regulated in the $\mathrm{CH}_{4} / \mathrm{NO}_{3}^{-}$continuous culture compared to the cells at $\mu_{\max }$. These observations are similar to the down-regulation of assimilatory nitrite and nitrate reductase genes in Methylocystis sp. strain SC2 under $30 \mathrm{mM}$ $\mathrm{NH}_{4}^{+}$compared to $10 \mathrm{mM}$ nitrate or $\mathrm{NH}_{4}^{+}$(Dam et al., 2014). It has been proposed that methanotrophs with denitrifying capacity might surpass other methanotrophs in ecosystems with high concentrations of nitrogen, because they have the ability to deal with reactive $\mathrm{N}$-compounds (Nyerges et al., 2010). The $\mathrm{NO}_{2}^{-}$reducing capacity of strain SolV helps this microorganism

\section{REFERENCES}

Acton, S. D., and Baggs, E. M. (2011). Interactions between $\mathrm{N}$ application rate, $\mathrm{CH} 4$ oxidation and $\mathrm{N}_{2} \mathrm{O}$ production in soil. Biogeochemistry 103, 15-26. doi: 10.1007/s10533-010-9442-5

Anvar, S. Y., Frank, J., Pol, A., Schmitz, A., Kraaijeveld, K., den Dunnen, J. T., et al. (2014). The genomic landscape of the verrucomicrobial methanotroph Methylacidiphilum fumariolicum SolV. BMC Genomics 15:914. doi: 10.1186/1471-2164-15-914

Bédard, C., and Knowles, R. (1989). Physiology, biochemistry, and specific inhibitors of $\mathrm{CH}_{4}, \mathrm{NH}_{4}^{+}$and $\mathrm{CO}$ oxidation by methanotrophs and nitrifiers. Microbiol. Rev. 53, 68-84.

Campbell, M. A., Nyerges, G., Kozlowski, J. A., Poret-Peterson, A. T., Stein, L. Y., and Klotz, M. G. (2011). Model of the molecular basis for hydroxylamine oxidation and nitrous oxide production in methanotrophic bacteria. FEMS Microbiol. Lett. 322, 82-89. doi: 10.1111/j.1574-6968.2011. 02340.x

Caranto, J. D., and Lancaster, K. M. (2017). Nitric oxide is an obligate bacterial nitrification intermediate produced by hydroxylamine oxidoreductase. Proc. Natl. Acad. Sci. U.S.A. 114, 8217-8222. doi: 10.1073/pnas.1704504114

Chaudhuri, R. R., Yu, L., Kanji, A., Perkins, T. T., Gardner, P. P., Choudhary, J., et al. (2011). Quantitative RNA- seq analysis of the Campylobacter jejuni transcriptome. Microbiology 157, 2922-2932. doi: 10.1099/mic.0.050278-0

Chistoserdova, L., Kalyuzhnaya, M. G., and Lidstrom, M. E. (2009). The expanding world of methylotrophic metabolism. Annu. Rev. Microbiol. 63, 477-499. doi: 10.1146/annurev.micro.091208.073600

Conrad, R. (2009). The global methane cycle: recent advances in understanding the microbial processes involved. Environ. Microbiol. Rep. 1, 285-292. doi: $10.1111 /$ j.1758-2229.2009.00038.x to balance assimilation and tolerance in response to reactive$\mathrm{N}$ molecules in the extreme conditions of its habitat. Our experiments show that strain SolV is well adapted to cope with the fluctuating conditions (presence of $\mathrm{H}_{2}$, differences in $\mathrm{NH}_{4}^{+}$ and $\mathrm{O}_{2}$ concentrations and $\mathrm{pH}$ ) that may occur in its natural environment.

\section{AUTHOR CONTRIBUTIONS}

SM, AP, MJ, and HO designed the project and experiments. Experimental work was performed by SM, TvA, and AP. SM and AP maintained the chemostat cultures. SM, TvA, AP, MJ, and $\mathrm{HO}$ performed data analysis and data interpretation. SM and $\mathrm{HO}$ wrote the manuscript with input from AP, TvA, and MJ. HO and MJ supervised the research.

\section{FUNDING}

SM was supported by the Spinoza grant of MJ (Netherlands Organization for Scientific Research) and the European Research Council (ERC Advanced Grant project VOLCANO 669371), MJ by the European Research Council (ERC Advanced Grant Eco_MoM 339880) and HO by the European Research Council (ERC Advanced Grant project VOLCANO 669371).

\section{SUPPLEMENTARY MATERIAL}

The Supplementary Material for this article can be found online at: http://journal.frontiersin.org/article/10.3389/fmicb. 2017.01901/full\#supplementary-material

Crombie, A. T., and Murrell, J. C. (2014). Trace-gas metabolic versatility of the facultative methanotroph Methylocella silvestris. Nature 510, 148-151. doi: 10.1038/nature13192

Dalton, H. (1977). Ammonia oxidation by the methane oxidising bacterium Methylococcus capsulatus strain bath. Arch. Microbiol. 114, 273-279. doi: 10.1007/BF00446873

Dam, B., Dam, S., Kim, Y., and Liesack, W. (2014). Ammonium induces differential expression of methane and nitrogen metabolism-related genes in Methylocystis sp. strain SC2. Environ. Microbiol. 16, 3115-3127. doi: 10.1111/1462-2920.12367

Dunfield, P. F., Yuryev, A., Senin, P., Smirnova, A. V., Stott, M. B., Hou, S., et al. (2007). Methane oxidation by an extremely acidophilic bacterium of the phylum Verrucomicrobia. Nature 450, 879-883. doi: 10.1038/nature06411

Ettwig, K. F., Shima, S., van de Pas-Schoonen, K. T., Kahnt, J., Medema, M. H., Op den Camp, H. J. M., et al. (2008). Denitrifying bacteria anaerobically oxidize methane in the absence of Archaea. Environ. Microbiol. 10, 3164-3173. doi: 10.1111/j.1462-2920.2008.01724.x

Hanson, R. S., and Hanson, T. E. (1996). Methanotrophic bacteria. Microbiol. Rev. $60,439-471$.

He, R., Chen, M., Ma, R. C., Sum, Y., and Zhang, X. (2017). Ammonium conversion and its feedback effect on methane oxidation of Methylosinus sporium. J. Biosci. Bioeng. 123, 466-473. doi: 10.1016/j.jbiosc.2016.11.003

Heyer, J., Berger, U., Hardt, M., and Dunfield, P. F. (2005). Methylohalobius crimeensis gen. nov., sp. nov., a moderately halophilic, methanotrophic bacterium isolated from hypersaline lakes of Crimea. Int. J. Syst. Evol. Microbiol. 55, 1817-1826. doi: 10.1099/ijs.0.63213-0

Hütter, L. A. (1992). Wasser und Wasseruntersuchung - Methodik, Theorie und Praxis chemischer, Chemisch-Physikalischer und Bakteriologischer Untersuchungsverfahren. Frankfurt: Salle. 
Im, J., Lee, S. W., Bodrossy, L., Barcelona, M. J., and Semrau, J. D. (2011). Field application of nitrogen and phenylacetylene to mitigate greenhouse gas emissions from landfill cover soils: effects on microbial community structure. Appl. Microbiol. Biotechnol. 89, 189-200. doi: 10.1007/s00253-010-2811-0

Islam, T., Jensen, S., Reigstad, L. J., Larsen, O., and Birkeland, N. K. (2008). Methane oxidation at 55 degrees $\mathrm{C}$ and $\mathrm{pH} 2$ by a thermoacidophilic bacterium belonging to the Verrucomicrobia phylum. Proc. Natl. Acad. Sci. U.S.A. 105, 300-304. doi: 10.1073/pnas.0704162105

Keltjens, J. T., Pol, A., Reimann, J., and Op den Camp, H. J. M. (2014). PQQdependent methanol dehydrogenases: rare-earth elements make a difference. Appl. Microbiol. Biotechnol. 98, 6163-6183. doi: 10.1007/s00253-014-5766-8

Khadem, A. F., Pol, A., Jetten, M. S. M., and Op den Camp, H. J. M. (2010). Nitrogen fixation by the verrucomicrobial methanotroph "Methylacidiphilum fumariolicum" SolV. Microbiology 156, 1052-1059. doi: 10.1099/mic.0.036061-0

Khadem, A. F., Pol, A., Wieczorek, A., Mohammadi, S. S., Francoijs, K. J., Stunnenberg, H. G., et al. (2011). Autotrophic methanotrophy in verrucomicrobia: Methylacidiphilum fumariolicum SolV uses the CalvinBenson-Bassham cycle for carbon dioxide fixation. J. Bacteriol. 193, 4438-4446. doi: 10.1128/JB.00407-11

Khadem, A. F., Pol, A., Wieczorek, A. S., Jetten, M. S. M., and Op den Camp, H. J. M. (2012a). Metabolic regulation of "Ca. Methylacidiphilum fumariolicum" SolV cells grown under different nitrogen and oxygen limitations. Front. Microbiol. 3:266. doi: 10.3389/fmicb.2012.00266

Khadem, A. F., van Teeseling, M. C., van Niftrik, L., Jetten, M. S. M., and Op den Camp, H. J. M. (2012b). Genomic and physiological analysis of carbon storage in the verrucomicrobial methanotroph "Ca. Methylacidiphilum fumariolicum" SolV. Front. Microbiol. 3:345. doi: 10.3389/fmicb.2012.00345

Khadem, A. F., Wieczorek, A. S., Pol, A., Vuilleumier, S., Harhangi, H. R., Dunfield, P. F., et al. (2012c). Draft genome sequence of the volcano-inhabiting thermoacidophilic methanotroph Methylacidiphilum fumariolicum strain SolV. J. Bacteriol. 194, 3729-3730. doi: 10.1128/JB.00501-12

Kits, K. D., Klotz, M. G., and Stein, L. Y. (2015). Methane oxidation coupled to nitrate reduction under hypoxia by the Gammaproteobacterium Methylomonas denitrificans, sp. nov. type strain FJG1. Environ. Microbiol. 17, 3219-3232. doi: $10.1111 / 1462-2920.12772$

Klotz, M. G., and Stein, L. Y. (2008). Nitrifier genomics and evolution of the nitrogen cycle. FEMS Microbiol. Lett. 278, 146-156. doi: 10.1111/j.1574-6968.2007.00970.x

Lee, S.-W., Im, J., Dispirito, A. A., Bodrossy, L., Barcelona, M. J., and Semrau, J. D. (2009). Effect of nutrient and selective inhibitor amendments on methane oxidation, nitrous oxide production, and key gene presence and expression in landfill cover soils: characterization of the role of methanotrophs, nitrifiers, and denitrifiers. Appl. Microbiol. Biotechnol. 85, 389-403. doi: 10.1007/s00253-009-2238-7

Mandernack, K. W., Kinney, C. A., Coleman, D., Huang, Y. S., Freeman, K. H., and Bogner, J. (2000). The biogeochemical controls of $\mathrm{N}_{2} \mathrm{O}$ production and emission in landfill cover soils: the role of methanotrophs in the nitrogen cycle. Environ. Microbiol. 2, 298-309. doi: 10.1046/j.1462-2920.2000.00106.x

Matthew, R., McIlvin, M. R., and Altabet, M. A. (2005). Chemical conversion of nitrate and nitrite to nitrous oxide for nitrogen and oxygen isotopic analysis in freshwater and seawater. Anal. Chem. 77, 5589-5595. doi: 10.1021/ac050528s

Megraw, S. R., and Knowles, R. (1987). Methane production and consumption in a cultivated humisol. Biol. Fertil. Soils 5, 56-60. doi: 10.1007/BF00264347

Mohammadi, S., Pol, A., van Alen, T. A., Jetten, M. S. M., and Op den Camp, H. J. M. (2017). Methylacidiphilum fumariolicum SolV, a thermoacidophilic 'Knallgas' methanotroph with both an oxygen-sensitive and -insensitive hydrogenase. ISME J. 11, 945-958. doi: 10.1038/ismej.2016.171

Mortazavi, A., Williams, B. A., McCue, K., Schaeffer, L., and Wold, B. (2008). Mapping and quantifying mammalian transcriptomes by RNA-Seq. Nat. Methods 5, 621-628. doi: 10.1038/nmeth.1226

Murrell, J. C., and Jetten, M. S. M. (2009). The microbial methane cycle. Environ. Microbiol. Rep. 1, 279-284. doi: 10.1111/j.1758-2229.2009. 00089.x
Nyerges, G., Han, S. K., and Stein, L. Y. (2010). Effects of ammonium and nitrite on growth and competitive fitness of cultivated methanotrophic bacteria. Appl. Env. Microbiol. 76, 5648-5651. doi: 10.1128/AEM.00747-10

Nyerges, G., and Stein, L. Y. (2009). Ammonia cometabolism and product inhibition vary considerably among species of methanotrophic bacteria. FEMS Microbiol. Lett. 297, 131-136. doi: 10.1111/j.1574-6968.2009.01674.x

O'Neill, J. G., and Wilkinson, J. F. (1977). Oxidation of ammonia by methaneoxidizing bacteria and the effects of ammonia on methane oxidation. J. Gen. Microbiol. 100, 407-412. doi: 10.1099/00221287-100-2-407

Op den Camp, H. J. M., Islam, T., Stott, M. B., Harhangi, H. R., Hynes, A., Schouten, S., et al. (2009). Environmental, genomic and taxonomic perspectives on methanotrophic Verrucomicrobia. Environ. Microbiol. Rep. 1, 293-306. doi: 10.1111/j.1758-2229.2009.00022.x

Pol, A., Barends, T. R., Dietl, A., Khadem, A. F., Eygensteyn, J., Jetten, M. S. M., et al. (2014). Rare earth metals are essential for methanotrophic life in volcanic mudpots. Environ. Microbiol. 16, 255-264. doi: 10.1111/1462-2920.12249

Pol, A., Heijmans, K., Harhangi, H. R., Tedesco, D., Jetten, M. S. M., and Op den Camp, H. J. M. (2007). Methanotrophy below pH 1 by a new Verrucomicrobia species. Nature 450, 874-878. doi: 10.1038/nature06222

Poret-Peterson, A. T., Grahamm, J. E., Gulledge, J., and Klotz, M. G. (2008). Transcription of nitrification genes by the methane-oxidizing bacterium, Methylococcus capsulatus strain Bath. ISME J. 2, 1213-1220. doi: 10.1038/ismej.2008.71

Ryabenko, E., Altabet, M. A., and Wallace, D. W. R. (2009). Effect of chloride on the chemical conversion of nitrate to nitrous oxide for $15 \mathrm{~N}$ analysis. Limnol. Oceanogr. Methods 7, 545-552. doi: 10.4319/lom.2009.7.545

Sharp, C. E., Op den Camp, H. J. M., Tamas, I., and Dunfield, P. F. (2013). “Unusual members of the PVC superphylum: the methanotrophic Verrucomicrobia genus "Methylacidiphilum"," in Planctomycetes: Cell Structure, Origins and Biology, ed J. A. Fuerst (New York, NY: Humana Press; Springer), 211-227.

Sharp, C. E., Smirnova, A. V., Graham, J. M., Stott, M. B., Khadka, R., Moore, T. R., et al. (2014). Distribution and diversity of Verrucomicrobia methanotrophs in geothermal and acidic environments. Environ. Microbiol. 16, 1867-1878. doi: 10.1111/1462-2920.12454

Sharp, C. E., Stott, M. B., and Dunfield, P. F. (2012). Detection of autotrophic verrucomicrobial methanotrophs in a geothermal environment using stable isotope probing. Front. Microbiol. 3:303. doi: 10.3389/fmicb.2012.00303

Stein, L. Y., and Klotz, M. G. (2011). Nitrifying and denitrifying pathways of methanotrophic bacteria. Biochem. Soc. Trans. 39, 1826-1831. doi: 10.1042/BST20110712

Stein, L. Y., Roy, R., and Dunfield, P. F. (2012). "Aerobic methanotrophy and nitrification processes and connections," in eLS (Chichester: John Wiley Sons, Ltd). doi: 10.1002/9780470015902.a0022213. Available online at: http://www. els.net

Taylor, S., Ninjoor, V., Dowd, D. M., and Tappel, A. L. (1974). Cathepsin B2 measurement by sensitive fluorometric ammonia analysis. Anal. Biochem. 60, 153-162. doi: 10.1016/0003-2697(74)90140-7

van Teeseling, M. C. F., Pol, A., Harhangi, H. R., van der Zwart, S., Jetten, M. S. M., Op den Camp, H. J. M., et al. (2014). Expanding the verrucomicrobial methanotrophic world: description of three novel species of Methylacidimicrobium gen. nov. Appl. Environ. Microbiol. 80, 6782-6791. doi: 10.1128/AEM.01838-14

Conflict of Interest Statement: The authors declare that the research was conducted in the absence of any commercial or financial relationships that could be construed as a potential conflict of interest.

Copyright (C) 2017 Mohammadi, Pol, van Alen, Jetten and Op den Camp. This is an open-access article distributed under the terms of the Creative Commons Attribution License (CC BY). The use, distribution or reproduction in other forums is permitted, provided the original author(s) or licensor are credited and that the original publication in this journal is cited, in accordance with accepted academic practice. No use, distribution or reproduction is permitted which does not comply with these terms. 